KS. ZBIGNIEW JANCZEWSKI

Wydział Prawa Kanonicznego

Uniwersytetu Kardynała Stefana Wyszyńskiego w Warszawie

\title{
PROBLEM RECEPCJI ADHORTACJI APOSTOLSKIEJ AMORIS LEATITIA W KWESTII PRZYSTĘPOWANIA DO SAKRAMENTÓW POKUTY I EUCHARYSTII OSÓB ROZWIEDZIONYCH
}

Treść: Wstęp. - 1. Argumenty za dopuszczeniem rozwiedzionych do sakramentów w dyskusji przed Synodami Biskupów z 2014 i 2015 r. - 2. Przystępowanie do Eucharystii według Familiaris consortio i Amoris laetitia. - 3. Interpretacje Amoris leatitia w kwestii przystępowania do sakramentów pokuty i Eucharystii osób rozwiedzionych dokonane przez kanonistów i teologów. - 4. Aplikacja adhortacji papieża Franciszka do warunków lokalnych. - Zakończenie.

\section{Wstęp}

Człowiek od początku swojej egzystencji na ziemi doświadcza zła wokół siebie i w sobie. Dotyczy to również relacji między mężczyzną i kobietą, ich związek jest zagrożony niezgodą, duchem panowania jednej osoby nad drugą, niewiernością, a także konfliktami nierzadko prowadzącymi do jego zerwania. Porządek stworzenia, pomimo poważnego naruszenia skutkami grzechu pierworodnego przetrwał, ale dla leczenia ran grzechowych mężczyzna i kobieta potrzebują pomocy łaski Bożej, bez której nie mogą urzeczywistniać wzajemnej jedności życia1. Taką łaskę otrzymują w sakramencie małżeństwa, następnie

\footnotetext{
${ }^{1}$ Katechizm Kościoła Katolickiego, Poznań 1994, nr 1608.
} 
jest ona wspierana dzięki pokucie i Eucharystii. Do istoty małżeństwa należy jego nierozerwalność. Niektórzy z małżonków decydują się czasami na odejście i życie z inną osobą w związku niesakramentalnym, formalnym lub nieformalnym, popełniając grzech ciężki i pozbawiając się tym samym prawa do Eucharystii. Z czasem jednak pojawia się u nich pragnienie powrotu do życia w pełnej wspólnocie z Kościołem, w tym również wspólnocie sakramentalnej. Z drugiej strony zobowiązania zaciągnięte wobec nowego partnera, czy dzieci nie pozwalają na porzucenie obecnego związku. Nad rozwiązywaniem tego rodzaju problemów pochylił się papież Franciszek zwołując w roku 2015 Zwyczajny Synod Biskupów oraz wydając posynodalną adhortację Amoris laetitia.

Wspomniany dokument papieski wzbudził wiele kontrowersji. Jedni jego komentatorzy uważali, że nie wniósł on niczego nowego w życie Kościoła inni, że papież dokonał swego rodzaju rewolucji w dyscyplinie, a nawet doktrynie. Celem niniejszej publikacji jest ukazanie recepcji wspomnianej adhortacji w Kościele katolickim. Artykuł składa się z czterech części. W pierwszej zostały przedstawione argumenty za dopuszczeniem osób rozwiedzionych do sakramentów pokuty i Eucharystii, wysuwane w publikacjach naukowych przed wspomnianym synodem. Kolejna część dotyczy możliwości przyjmowania tych sakramentów według adhortacji apostolskich Familiaris consortio i Amoris laetitia. W części trzeciej ukazane zostały różne interpretacje drugiego ze wspomnianych dokumentów dokonywane przez kanonistów i teologów w zakresie interesującej nas kwestii. Ostatni fragment artykułu dokonuje analizy aplikacji postanowień adhortacji papieża Franciszka do warunków lokalnych, dokonanych przez niektóre Konferencje Biskupów. Publikacja ta stanowi głos w naukowej dyskusji dotyczącej możliwości i warunków przystępowania do sakramentu pokuty i Komunii św. małżonków żyjących w nowych związkach po rozpadzie ich małżeństwa sakramentalnego. 


\section{Argumenty za dopuszczeniem rozwiedzionych do sakramentów w dyskusji przed Synodami Biskupów z 2014 i 2015 r.}

Adhortacja Amoris laetitia papieża Franciszka ukazała się po zakończeniu obrad dwóch Zgromadzeń Synodu Biskupów, III Nadzwyczajnego Ogólnego, który miał miejsce w 2014 r. oraz XIV Zwyczajnego Ogólnego z 2015 r., które zajmowały się problematyką małżeństwa i rodziny, w tym również kwestią możliwości dopuszczania osób rozwiedzionych do sakramentów pokuty i Eucharystii. Jednakże już przed wspomnianymi synodami w środowiskach naukowych pojawiły się dyskusje dotyczące tego problemu.

Włoski naukowiec Giovanni Ceretti w swojej monografii wychodzi od postanowienia starożytnego Soboru Nicejskiego z 325 r., gdzie w kan. 8 postawiono warunki umożliwiające powrót do wspólnoty Kościoła członkom sekty Nowacjana. Musieli oni pozostać we wspólnocie z osobami odrzucanymi przez Nowacjan, które dwukrotnie zawierały małżeństwo, a także $\mathrm{z}$ upadłymi podczas prześladowań, którym wyznaczono czas za odbycie pokuty za ten czyn ${ }^{2}$. Według Cerettiego, termin „digami”, użyty w cytowanej normie, odnosił się zarówno do osób zawierających drugie małżeństwo po śmierci pierwszego współmałżonka, jak również do zawierających powtórny związek, po rozpadzie pierwszego. Autor opowiada się za stosowaniem tej starożytnej praktyki w dzisiejszych czasach, czyli za dopuszczaniem małżonków, którzy po rozwodzie zawarli kontrakt cywilny z kolejną osobą do przyjmowania Komunii św. Warunkiem byłoby okazanie żalu z powodu zerwania sakramentalnego małżeństwa, odbycie odpowiedniej pokuty i posiadanie woli rozpoczęcia nowej drogi wobec Boga. Dopuszczenie tych osób do wspomnianego sakramentu, stałoby się znakiem miłosierdzia okazywanego przez Pana Boga, a także zrozumienia ich trudnej sytuacji przez wspólnotę kościelną․

\footnotetext{
${ }^{2}$ Kanony, w: Dokumenty soborów powszechnych, red. A. Baron, H. Pietras, t. 1, Kraków 2002, s. 34-35.

${ }^{3}$ G. Ceretti, Divorzio, nuove nozze e penitenza nella Chiesa primitiva, Roma 2013, s. 433-437.
} 
W polemikę z cytowanym autorem wszedł Attilo Carpin, twierdząc, że termin „digami” nie odnosił się do drugiego małżeństwa zawartego za życia pierwszego współmałżonka. Miałaby na to wskazywać praktyka Kościoła starożytnego, niedopuszczania osób rozwiedzionych po zawarciu kolejnego związku do Eucharystii ${ }^{4}$.

W Polsce przed obradami wspomnianych dwóch synodów omawianą problematyką zajmował się autor niniejszego opracowania. $\mathrm{W}$ tym kontekście rozważane były dwa rozwiązania. W pierwszym z nich zauważył, iż praktyka dopuszczania do przyjmowania Eucharystii osób rozwiedzionych i żyjących w ponownym związku, istnieje w niekatolickich Kościołach wschodnich. Wynika ona z odmiennej niż katolicka koncepcji nierozerwalności sakramentalnego małżeństwa. W interesującej nas sytuacji prawosławni stosują tzw. zasadę oikonomii, która ma prowadzić wspomniane osoby do zbawienia, umożliwiając upadłym na skutek grzechu osiągnięcie życia wiecznego. Prawosławni uważają zatem, iż nie należy pozostawiać małżonków bez udziału łaski płynącej z przyjmowania Komunii św. Tolerowanie kolejnego, już niesakramentalnego związku w kontekście przystępowania do Eucharystii, jest dla niekatolickich Kościołów wschodnich lekarstwem i ochroną, aby na stałe nie pozostawiać wspomnianych osób w grzechu.

Trzeba tu również zauważyć pewną analogię do katolickiego postrzegania swoich wiernych, zawierających za dyspensą związek małżeński z osobami nieochrzczonymi. Takie małżeństwo jest tolerowane przez Kościół katolicki, pomimo że nie uważa się go za sakramentalne, a katolicki małżonek zachowuje możliwość przyjmowania Ciała Chrystusa ${ }^{5}$.

${ }^{4}$ A. CARpin, Indissolubilità del matrimonio. La tradizione della Chiesa antica, Bologna 2014, s. 278-284.

${ }^{5}$ Z. JANCZEWski, Przyjmowanie Eucharystii przez osoby żyjące $w$ małżeństwach niesakramentalnych, w: Reddite ergo quae sunt caesaris caesari et quae sunt Dei Deo. Księga jubileuszowa dedykowana ks. Prof. Józefowi Krukowskiemu z okazji 50-lecia pracy naukowej, red. M. Sitarz, P. Stanisz, H. Stawniak, Lublin 2014, s. 409-410. Jeszcze na początku XXI w. w kanonistyce spierano się o charakter sakramentalny takiego małżeństwa. Dopiero po ukazaniu się Norm Kongregacji Doktryny Wiary 
Innym rozwiązaniem problemu będzie uznanie, że osoby powołane przez Stwórcę do prowadzenia życia małżeńskiego i rodzinnego, posiadają zazwyczaj silną potrzebę tworzenia wspólnoty oraz współżycia ze swoim współmałżonkiem na płaszczyźnie seksualnej. A zatem, nie można odmawiać pozostawionej samej sobie osobie, po odejściu współmałżonka, jej naturalnego prawa do życia w rodzinie. W takim kontekście, jak pisał autor niniejszej publikacji, należy się zastanowić, że skoro główną przeszkodą dla osoby pozostającej w związku cywilnym, po rozpadzie małżeństwa sakramentalnego jest popełnianie przez nią grzechu cudzołóstwa (w czasie współżycia seksualnego), a grzech ten ze swojej natury jest kwalifikowany jako ciężki, czy zatem współżycie takowe w przypadku każdej osoby posiada znamiona dobrowolności. Czy na działanie w pełni dobrowolne decyduje się np. osoba nie posiadająca możliwości samotnie wychować i utrzymać swoich dzieci, które przyszły na świat z jej sakramentalnego, lub kolejnego małżeństwa. Jeżeli zatem jej wolność wewnętrzna jest ograniczona, grzech który popełnia nie spełnia jednej z trzech przesłanek koniecznych do uznania go za ciężki, czyli uniemożliwiający przyjmowania Eucharystii. Ponadto wychodząc z Chrystusowego założenia, że to nie człowiek jest dla szabatu, a szabat dla człowieka, można analogicznie powiedzieć, iż nie człowiek został stworzony dla sakramentów, tylko sakramenty dla niego, aby pomagać mu w osiąganiu ideału świętości ${ }^{6}$. Sakrament małżeństwa jest zatem Bożym narzędziem pomagającym w życiu małżeńskim, a nie celem, któremu to życie ma się całkowicie podporządkowywać.

W dniach 21-22 lutego 2014 r. odbywał się w Watykanie nadzwyczajny konsystorz Kolegium Kardynalskiego, stanowiący swego rodzaju wprowadzenie do późniejszego synodu biskupów. Rolę głównego referenta pełnił na nim kard. Walter Kasper. Postawił on

o rozwiązywaniu małżeństwa na korzyść wiary z 30.04.2001 r., autor niniejszego artykułu jako pierwszy w swojej publikacji postawił tezę o niesakramentalności małżeństwa osoby ochrzczonej z nieochrzczoną, por. Z JANCzEwski, Małżeństwo niesakramentalne chrześcijan, Ius Matrimoniale 12 (18) (2007), s. 39-40.

${ }^{6}$ Z. JANCZEWski, Przyjmowanie Eucharystii..., s. 409-410. 
zebranym kilka istotnych pytań. Czy osoby pozostające w nowych związkach po rozpadzie ich sakramentalnego małżeństwa, które żałują za takowy rozpad, uregulowały już swoje obowiązki wypływające z małżeństwa sakramentalnego, definitywnie nie widzące możliwości powrotu do pierwotnego związku i równocześnie usiłujące żyć w drugim związku możliwie jak najlepiej według zasad wyznawanej wiary, wychowując w niej potomstwo, czy w okresie ich przemiany wewnętrznej nie należy dopuścić do sakramentu pokuty i Eucharystii. Cytowany teolog skłania się ku takiemu właśnie rozwiązaniu, zaznaczając, iż każdy przypadek należałoby traktować indywidualnie. Kasper odwołał się równocześnie do starożytnej praktyki pokutnej Kościoła stosowanej do tzw. upadłych, czyli lapsi ${ }^{7}$.

Po zakończeniu XIV Zgromadzenia Zwyczajnego Synodu Biskupów z 2015 r. ukazał się oficjalny dokument, stanowiący relację końcową obrad ${ }^{8}$. Jak uważa Wojciech Góralski, tekst relacji nie pozwala przyjąć, iż małżonka pozostającego w związku nieregularnym, który nie spełnia warunków stawianych przez adhortację apostolską Familiaris consortio papieża Jana Pawła II, wolno dopuszczać do Komunii św. Z drugiej strony należy jednak uznać, że niektóre sformułowania dokumentu z 2015 r. są dwuznaczne i mogą prowadzić do interpretacji dopuszczającej go do "pełniejszego” uczestnictwa w Eucharystii, po „rozeznaniu” sytuacji małżonków ${ }^{9}$.

\section{Przystępowanie do Eucharystii według Familiaris consortio i Amoris laetitia}

Pierwszym dokumentem dopuszczającym osoby rozwiedzione, żyjące w związku cywilnym z nowym partnerem była wydana 22 listopada 1981 r. adhortacja apostolska Familiaris consortio papieża

${ }^{7}$ F. R. Aznar GiL, El debate sinodal (2014) sobre la situación eclesial de los fieles divorciados y casaos de nuevo civilmente, Appolinaris 87(2014) nr 2, s. 467-470; W. CAsper, Il Vangelo della famiglia, Brescia 2014, s. 5.

${ }^{8} \mathrm{http}: / /$ press.vatican.va/content/salastampa/enbollettino/pubblico/0816/01825. html, [dostęp: 9.07.2018, g. 11.30].

${ }^{9}$ W. Góralski, Sprawiedliwość czy miłosierdzie? Problem Komunii Świętej katolików rozwiedzionych i żyjących $w$ małżeństwie cywilnym, Płock 2016, s. 28-29. 
Jana Pawła II. Jan Paweł II dostrzega w nim coraz bardziej upowszechniające się zjawisko rozwodów cywilnych, które ma miejsce nawet wśród katolików oraz zawierania nowych związków cywilnych. Papież wzywa duszpasterzy do właściwego rozeznawania sytuacji osób żyjących w tego rodzaju związkach, a także okazywania im pomocy i podejmowania starań o to, aby nie czuli się odłączeni od Kościoła. Jako osoby ochrzczone mogą bowiem, a nawet mają powinność, uczestniczyć w jego życiu. Z drugiej zaś strony Ojciec św. potwierdza praktykę Kościoła niedopuszczania do przyjmowania Eucharystii rozwiedzionych, którzy zawarli nowy związek cywilny, ponieważ ich stan i sposób życia obiektywnie zaprzeczają więzi miłości między Chrystusem i Kościołem, wyrażaną i urzeczywistnianą w tym sakramencie. Dopuszczenie do Komunii św. wprowadzałoby wiernych w błąd, albo powodowało zamęt w odniesieniu do nauki Kościoła o nierozerwalności małżeństwa ${ }^{10}$.

Dalsza część cytowanego dokumentu wprowadza jednak w dyscyplinie kościelnej nowość. Jan Paweł II stwierdza bowiem, że pojednanie w sakramencie pokuty otwiera niektórym drogę do przyjmowania Eucharystii, o ile żałując, że naruszyli znak Przymierza i wierności Chrystusowi, są szczerze gotowi na formę życia nie stojącą w sprzeczności z nierozerwalnością małżeństwa. Chodzi konkretnie o sytuacje kiedy mężczyzna i kobieta w kolejnym związku już niesakramentalnym, z ważnych powodów, na przykład dla wychowania dzieci, nie mogąc doprowadzić do rozstania się, postanawiają żyć w pełnej wstrzemięźliwości seksualnej, czyli powstrzymując się od aktów przysługujących małżonkom ${ }^{11}$.

Jakie wnioski wynikają $\mathrm{z}$ takiego postawienia interesującej nas kwestii? Należy mocno podkreślić, że to Jan Paweł II, a nie Franciszek, stał się pierwszym nowożytnym papieżem dopuszczającym wiernych żyjących po rozpadzie związku sakramentalnego, z nowymi osobami na tzw. kontrakcie cywilnym, do przyjmowania Komunii

\footnotetext{
${ }^{10}$ Jan Pawe€ II, Adhortacja apostolska Familiaris consortio o zadaniach rodziny chrześcijańskiej w świecie współczesnym, Częstochowa 1982, nr 84.

${ }^{11}$ Tamże.
} 
św. Stworzyło to poważne novum w Kościele. Dalej, uświadomił on fakt, iż główną przeszkodę dla udzielania im Eucharystii stanowi nie tyle wcześniejszy czyn odejścia od współmałżonka godzący w nierozerwalność małżeństwa sakramentalnego, który może być już nieodwracalny kiedy jedna ze stron kategorycznie odrzuca powrót do wspólnoty małżeńskiej, ale ciągłe trwanie w grzechu ciężkim poprzez współżycie seksualne z nowym partnerem w związku cywilnym, czyli popełnianie grzechu cudzołóstwa. Potwierdza to poźniejszy dokument tego papieża - Katechizm Kościoła Katolickiego, w którym czytamy, iż interesujące nas osoby nie mogą przystępować do Komunii eucharystycznej tak długo, jak długo znajdują się w sytuacji obiektywnie wykraczającej przeciwko prawu Bożemu popełniając cudzołóstwo. Pojednanie w sakramencie pokuty może nastąpić w odniesieniu do tych, którzy żałują złamania znaku Przymierza i wierności Chrystusowi i zobowiązują się żyć w całkowitej wstrzemięźliwości ${ }^{12}$.

Dnia 19 marca 2016 r. papież Franciszek podpisuje posynodalną adhortację apostolską Amoris laetitia o miłości w rodzinie. Jak już wcześniej zauważył autor niniejszego opracowania, twórca tego dokumentu nie poszedł, co jest zrozumiałe, drogą zmiany doktryny dotyczącej nierozerwalności małżeństwa sakramentalnego, natomiast podjął się odważnej próby bardziej złożonej oceny moralnej postępowania osób żyjących poza swoim związkiem sakramentalnym, związanych teraz z innym partnerem życiowym tworząc z nim nową rodzinę, w kontekście ich uczestnictwa w Eucharystii ${ }^{13}$.

Pisząc o sakramencie małżeństwa papież zauważa, że nie jest on umową społeczną, pustym rytuałem, ale darem dla uświęcenia i zbawienia małżonków. Małżeństwo to powołanie, ponieważ staje się odpowiedzią na specyficzne wezwanie przeżywania miłości mężczyzny i kobiety jako niedoskonałego znaku miłości pomiędzy Chrystusem a Kościołem. Nowożeńcy przysięgają sobie wzajemne oddanie, wierność i otwartość na życie. Chrystus przez swój sakrament pozostaje

\footnotetext{
${ }^{12}$ Katechizm Kościoła Katolickiego, Poznań 1994, nr 1650.

${ }^{13}$ Z. JANCZEWski, Udzielanie Komunii św. osobom rozwiedzionym? Analiza adhortacji Amoris laetitia papieża Franciszka, Prawo Kanoniczne 59(2016) nr 2, s. 44-45.
} 
z nimi, dając równocześnie moc pójścia za Nim i wzięcia na siebie swojego krzyża, podnoszenia się po upadkach, przebaczania, wzajemnego noszenia swoich ciężarów. Złączenie małżonków w jedno ciało, reprezentuje zaślubiny Syna Bożego z naturą ludzką. Natomiast ich zjednoczenie seksualne, po ludzku przeżywane i uświęcane przez sakrament, stanowi drogę wzrastania w życiu łaską, „misterium małżeństwa" ${ }^{14}$. W cytowanym dokumencie, co trzeba podkreślić, papież Franciszek potwierdza dotychczasową doktrynę Kościoła w odniesieniu do świętości i nierozerwalności małżeństwa i jego roli w życiu ochrzczonych.

Zauważa także problemy osób żyjących w nowych związkach, po rozpadzie małżeństwa sakramentalnego. Powinny one odczuwać, że w dalszym ciągu są częścią Kościoła, a ich sytuacja wymaga uważnego rozeznania i towarzyszenia $\mathrm{z}$ wielkim szacunkiem oraz popierania udziału w życiu tej wspólnoty. Troska o nich nie osłabia Kościoła, jego wiary i świadectwa o nierozerwalności małżeństwa, ponieważ w takiej trosce wyraża on swoją miłośćc ${ }^{15}$.

Stopień odpowiedzialności małżonków za rozpad ich związku nie jest równy w każdym przypadku, stąd mogą wystąpić czynniki ograniczające zdolność podejmowania przez nich decyzji. W odniesieniu do dyscypliny sakramentalnej po procesie rozeznania można więc uznać, że w danej sytuacji nie zaistniała poważna wina ${ }^{16}$. Już od Soboru Jerozolimskiego drogą Kościoła stała się droga Chrystusa, czyli miłosierdzia i integracji, niepotępiania nikogo na wieczność, ofiarowanie miłosierdzia Bożego wszystkim o nie proszącym, bowiem prawdziwa miłość jest zawsze bezwarunkowa, bezinteresowna i niezasłużona ${ }^{17}$.

\footnotetext{
${ }^{14}$ Franciszek, Posynodalna adhortacja apostolska Amoris laetitia o miłości w rodzinie, Kraków 2016, nr 72-74; Dalej używam skrótu; AL.

${ }^{15}$ Tamże, nr 243.

${ }^{16}$ AL, nr 79; przypis nr 336.

${ }^{17}$ Franciszek, Przemówienie do nowo mianowanych kardynałów, 15.02.2016, AAS 107(2015), s. 257.
} 
Osoby rozwiedzione żyjące w nowym związku mogą się znaleźć w różnych sytuacjach, których nie należy zbyt surowo oceniać. I tak przykładowo, czym innym jest drugi związek, umocniony z upływem czasu, posiadający własne dzieci, sprawdzoną wierność, poświęcenie, chrześcijańskie zaangażowanie, świadomość nieprawidłowości swojej sytuacji oraz trudności w cofnięciu się wstecz bez popadnięcia w nowe winy $^{18}$. Już Jan Paweł II w adhortacji Familiaris consortio uznał niejako za usprawiedliwione sytuacje, kiedy mężczyzna i kobieta dla ważnych powodów, na przykład wychowania dzieci, nie mogą uczynić zadość obowiązkowi rozstania się ${ }^{19}$. Z podobnym przypadkiem można się spotkać gdy osoba podjęła wielki wysiłek ratowania swojego małżeństwa sakramentalnego, doznając niestety niesprawiedliwego porzucenia. Również się zdarza zawarcie nowego związku ze względu na wychowanie dzieci, przy czym pozostaje się subiektywnie pewnym w sumieniu, iż wcześniejsze małżeństwo, które zostało nieodwracalnie zniszczone nie było ważnie zawarte ${ }^{20}$.

Papież Franciszek zachęca do odpowiedzialnego rozeznania, osobistego i duszpasterskiego każdego indywidualnego przypadku²1. Zadaniem kapłanów jest towarzyszenie zainteresowanym osobom na takiej drodze rozeznania, rozmowa na forum wewnętrznym przyczyniająca się do stworzenia prawidłowej oceny tego co utrudnia możliwość pełniejszego uczestnictwa w życiu Kościoła. Nie można bowiem twierdzić, że wszyscy znajdujący się w tzw. sytuacji nieregularnej, żyją w stanie grzechu śmiertelnego, będąc pozbawieni łaski uświęcającej. Osoby, które dobrze znają normę moralną, mogą posiadać poważne trudności w zrozumieniu zawartych w niej wartości, lub też znajdować się w określonych warunkach, niepozwalających na inne działanie i podejmowania nowych decyzji bez zaciągania następnej

\footnotetext{
${ }^{18}$ AL, nr 298.

${ }^{19}$ Jan Pawe£ II, Adhortacja apostolska Familiaris consortio..., nr 84.

${ }^{20}$ Tamże.

${ }^{21} \mathrm{AL}, \mathrm{nr} 300$.
} 
winy. Zatem według Franciszka, mogą zaistnieć czynniki ograniczające zdolność podejmowania decyzji przez wspomniane osoby ${ }^{22}$.

A zatem biorąc pod wagę konkretne uwarunkowania, należy bardziej doceniać rolę sumienia w praktyce Kościoła, szczególnie w niektórych sytuacjach, obiektywnie odbiegających od katolickiego rozumienia małżeństwa. Bowiem sumienie może uznać nie tylko to że konkretna sytuacja obiektywnie nie odpowiada ogólnym postanowieniom Ewangelii, lecz także szczerze i uczciwie stwierdzić, że to co w danej chwili jest wielkoduszną odpowiedzią jaką można dać Bogu, odkrywając z pewnością moralną, że jest to dar wymagany przez samego Boga, pośród złożoności ograniczeń, pomimo, że nie jest to $\mathrm{w}$ pełni obiektywny ideał. Takowe rozeznanie jest procesem posiadającym swój dynamizm, który pozwala z czasem na zrealizowanie ideału w pełniejszy sposób. Stąd też, ze względu na uwarunkowania i czynniki łagodzące, jest możliwe, że pośród pewnej obiektywnej sytuacji grzechu, osoba która nie jest subiektywnie, albo w pełni winna, może jednak żyć w łasce Bożej, kochać oraz wzrastać w życiu łaski i miłości, otrzymując w tym celu pomoc Kościoła. Eucharystia bowiem nie jest nagrodą dla doskonałych, ale szlachetnym lekarstwem dla słabych ${ }^{23}$.

Papież podkreśla jednak, że zrozumienie sytuacji wyjątkowych, nigdy nie oznacza ukrywania światła pełniejszego ideału, ani też proponowania mniej niż to, co Chrystus ofiaruje człowiekowi, stąd dzisiaj bardziej istotny staje się duszpasterski wysiłek na rzecz umacniania małżeństw i zapobiegania ich rozpadom, niż duszpasterstwo niepowodzeń ${ }^{24}$.

\footnotetext{
${ }^{22}$ Tamże, nr 300-301.

${ }^{23}$ Tamże, nr 303; 305.

${ }^{24}$ Tamże, nr 307.
} 


\section{Interpretacje Amoris leatitia w kwestii przystępowania do sakramentów pokuty i Eucharystii osób rozwiedzionych dokonane przez kanonistów i teologów}

Jak to już zostało powiedziane, papież Jan Paweł II w adhortacji Familiaris consortio dopuścił możliwość rozgrzeszania osób pozostających w powtórnych związkach, o ile zachowują one pełną wstrzemięźliwość seksualną. Bo jak zauważa Paweł Grad, nie popadają one wtedy w konflikt z naturą wiążącego ich sakramentu, nie zaciągając grzechu ciężkiego. Dyskusja, która pojawiła się po adhortacji Franciszka dotyczy zatem możliwości dopuszczania do Eucharystii osób żyjących w powtórnych związkach, które decydują się na pełne współżycie ${ }^{25}$. Przypatrzmy się zatem tej dyskusji, przywołując poglądy współczesnych naukowców.

Wśród zachodnich teologów podzielających powyższą opinię jest kard. Gerhard L. Muller. Według niego przypis nr 351 mówiący o pomocy sakramentalnej dla interesujących nas osób, odnosi się ogólnie do obiektywnych sytuacji grzechu, a nie do konkretnego przypadku rozwiedzionych, po wstąpieniu przez nich w nowe związki ${ }^{26}$.

Zdaniem Antonio Liviego, niezawiniony brak wiedzy w przedmiocie czynu ocenianego obiektywnie jako grzech ciężki, którym jest cudzołóstwo oraz trudność w prowadzeniu życia wiernego Ewangelii, nie upoważniają małżonka, który nie poczuwa się do winy subiektywnej do otrzymania rozgrzeszenia. Spowiednik w takim przypadku ma za zadanie skorygować błąd penitenta, pouczając i przekonując go do pokonania swoich trudności i powrotu do życia według zasad Pisma św. ${ }^{27}$

Eklezjolog Massimo Nardello uważa, że interesujący nas dokument papieski nie zajmuje się problemem przyjmowania Komunii św. przez

${ }^{25}$ P. Grad, Unieszkodliwianie Magisterium. Studium dyskusji o Amoris laetitia, Christianitas 65(2016), s. 42-43.

${ }^{26}$ Kard. Muller rozstrzygnął spór o Komunię dla rozwodników po Amoris laetitia, http://pl.radiovaticana.va/news/2016/05/04/kard._m\%B3w_po_127545, [dostęp: 10.07.2018, g. 9.15].

${ }^{27}$ A. Livi, Doktryna moralna i praxis duszpasterstwa w Amoris laetitia, http:// gloria.tv/article/h3E9c4fulCcHucTXf2LKKZx5, [dostęp: 10.07.2018, g. 9.30]. 
osoby rozwiedzione żyjące w nowych związkach. Zasady, które przytacza, mają z natury jedynie charakter ogólny, nie dotycząc wyłącznie przypadku pozostających w tzw. związkach „nieregularnych”28.

Mniej radykalnie odczytuje adhortację papieża Franciszka Jan Dyduch. Pisze on, że papież nie mówi ani o zasadach, ani o konkretnych okolicznościach dopuszczania do sakramentów osób rozwiedzionych po zawarciu nowego związku. Wielokrotnie natomiast przywołuje zasadę nierozerwalności małżeństwa sakramentalnego. Stąd problem ten wymaga zarówno interpretacji naukowej, dokonywanej przez ekspertów, jak i urzędowej, czyli postanowień Konferencji Biskupów. Dokument papieski sugerując poszerzenie możliwości odwoływania się do miłosierdzia Bożego, nie określa ich precyzyjnie, pozostawiając sytuację otwartą na różne interpretacje ${ }^{29}$.

Inny polski kanonista Wojciech Góralski, niemożliwość udzielenia rozgrzeszenia osobom dopuszczającym się cudzołóstwa poprzez współżycie w nowym związku, widzi w braku określonej dyspozycji ich samych, niezbędnej do otrzymana przebaczenia i podjęcia drogi nawrócenia. Jego zdaniem zwolennicy dopuszczania do Eucharystii, zdają się nie brać tego pod uwagę, zwracając całą uwagę na ich żal i pokutę za zerwanie poprzedniego małżeństwa ${ }^{30}$. Okazanie szczerej skruchy i żalu za popełniony grzech przez małżonka winnego za to co się stało, nie wystarczy do otrzymania rozgrzeszenia. Należy bowiem zdecydowanie odróżnić winę moralną oraz odpowiedzialność za wybory dokonane w przeszłości, od tego co dotyczy aktualnej sytuacji. Tym co nie jest do pogodzenia z rozgrzeszeniem w sakramencie pokuty i przyjęciem Komunii św., są bowiem nie tyle grzechy dawne, ale aktualna wola prowadzenia życia w sprzeczności

\footnotetext{
${ }^{28}$ M. NARdello, Amoris laetitia: osservazioni teologiche (23.05.2016), commento, http://familiacristiana.it/articolo/amoris-laetitia, s.3, [dostęp: 10.07.2018, g. 10.00].

${ }^{29} \mathrm{~J}$. Dyduch, Adhortacja Amoris laetitia twórczą kontynuacją adhortacji Familiaris consortio? w: Dyskusje nad Amoris laetitia, red. P. Kroczek, Annales Canonici Monographiae, nr 6, Kraków 2017, s. 43-44.

${ }^{30}$ W. Góralski, Sprawiedliwość czy miłosierdzie..., s. 57-58.
} 
z sakramentalnością małżeństwa ${ }^{31}$. W odniesieniu do postanowień franciszkowej adhortacji, wydaje się, jak pisze Góralski, że w grę może wchodzić jedynie sytuacja, w której rozwiedzeni małżonkowie trwający w nowym związku, po rozeznaniu z pomocą spowiednika, albo kierownika duchowego, decydują się żyć ze sobą „jak brat z siostrą", a zatem zachowywać całkowitą wstrzemięźliwość seksualną. Jednakże w przypadku gdyby w jakimś momencie nie dotrzymali swojego postanowienia i podczas spowiedzi wyznali swój grzech upadku, spowiednik upewniwszy się, że osoby te dalej pragną trwać w czystości, mógłby ponownie udzielić każdemu z nich absolucji ${ }^{32}$.

Trzeba zauważyć, iż przytoczone powyżej opinie uczonych wskazują, że adhortacja Amoris laetitia jest jedynie potwierdzeniem nauczania poprzednich papieży i nie wnosi niczego nowego ani do doktryny o małżeństwie, ani też do dyscypliny Kościoła. Czy rzeczywiście papieżowi Franciszkowi, zauważającemu istotne i bardzo poważne problemy współczesnych małżeństw, chodziło jedynie o przypomnienie wcześniejszego nauczania? Część kanonistów i teologów, jest odmiennego zdania. Należy do nich James Martin. Koncentruje się o na użytym w papieskim dokumencie słowie kluczu „rozeznawanie”. Rozeznawanie bierze pod uwagę bogactwo i złożoność życia człowieka, zakładając, że w procesie dokonywania wyboru przez człowieka ma miejsce aktywność Boga. W ujęciu papieża Franciszka takie rozeznanie jest ściśle powiązane $\mathrm{z}$ pojęciem sumienia, szczególnie w przypadku osób stających w obliczu konieczności podjęcia skomplikowanych decyzji duchowych. Jest sztuką podejmowania decyzji na modlitwie, korzystająca z konkretnych praktyk duchowych. Adhortacja skierowana jest nie tylko do rodzin i indywidualnych chrześcijan, ale też do kapłanów i osób odpowiedzialnych za pomaganie $\mathrm{w}$ formowaniu sumień. Należy pamiętać, iż

\footnotetext{
${ }^{31}$ W. Góralski, Adhortacja apostolska Amoris laetitia papieża Franciszka. Prezentacja dokumentu z komentarzem do nn. 300-308, Płock 2016, s. 61.

32 Tamże, s. 69-70.
} 
Bóg chce pomagać człowiekowi w podejmowaniu dobrych decyzji, a człowiek wsłuchując się we własne serce może usłyszeć Jego głos ${ }^{33}$.

Według kanonisty Piotra Steczkowskiego, przedmiotem rozeznania jest aplikacja norm prawa moralnego i kanonicznego do konkretnego wiernego. Wszelkie normy prawa, w tym także Bożego, posiadają charakter ogólny i abstrakcyjny, zakładając określoną, hipotetyczną sytuację. Normy, będące wzorcami pożądanych zachowań, spełniają swoje zadania w momencie ich aplikacji do konkretnych sytuacji życiowych. Aplikacja norm musi zawsze uwzględniać konkretną sytuację, czyli to, co papież Franciszek określa mianem okoliczności. Akt rozeznania ma być czynnością polegającą na rozpoznawaniu okoliczności w których dana osoba aplikowała normę, co jest konieczne dla prawidłowej oceny odpowiedzialności człowieka. Należy przy tym pamiętać o zasadzie „słuszności kanonicznej”, nakazującej stosowanie prawa kanonicznego $\mathrm{z}$ uwzględnieniem racji salus animarum. Charakter rozeznania duszpasterskiego musi zawsze uwzględniać prawny wymiar sakramentów ${ }^{34}$. Ostatecznie to szafarz sakramentu decyduje po rozeznaniu o dopuszczeniu wiernego do Eucharystii. Prawo ma chronić wiernych przed arbitralnymi decyzjami, stąd potrzeba sformułowania jasnych kryteriów podejmowania takich decyzji. Wydaje się, iż papież Franciszek położył nacisk nie na precyzję obiektywnych przesłanek i warunków dopuszczania do Komunii interesujących nas osób, ale na osąd duszpasterza będącego ich kierownikiem duchowym. Powierzenie takiej decyzji duszpasterzowi, nie jest w Kościele ani nowością, ani odejściem od zasad kanonicznych ${ }^{35}$.

Rzeczywistą aplikacją Amoris laetitia do konkretnych problemów małżonków zajął się w swojej książce kard. Lluis Martinez Sistach. Zwraca uwagę na fakt, że w kontekście tego dokumentu nie należy

\footnotetext{
${ }^{33}$ J. Martin, Klucz do Amoris laetitia, http://wiez.com.pl/2016/07.16/klucz-do-amoris-laetitia/, [dostęp: 12.07.2018, g. 9.00].

${ }^{34}$ P. STeczKowski, Dopuszczenie do Komunii Świętej osób żyjących po małżeńsku bez mał̇̇eństwa - norma czy subiektywna ocena?, w: Dyskusje nad Amoris laetitia, red. P. Kroczek, Annales Canonici Monographiae, nr 6, Kraków 2017, s. 88-89.

${ }^{35}$ Tamże, s. 89-90.
} 
mówić o dopuszczaniu do sakramentów, ale o procesie towarzyszenia duszpasterza na drodze Jezusa prowadzącej ku miłosierdziu i integracji. Droga ta nie zawsze kończy się dopuszczeniem, może również skierować się ku innym formom integracji niż przez przyjmowanie sakramentów, np. w stronę większej obecności we wspólnocie, uczestnictwie w grupach modlitewnych lub medytacyjnych. Adhortacja otwiera również możliwość przystępowania przez interesujące nas osoby do pokuty i Eucharystii, które wspomagają dalsze kontynuowanie przez nich procesu dojrzewania i wzrastania dzięki mocy łaski Bożej. Możliwość taka nie jest prostym, automatycznym dopuszczeniem do sakramentów, ale opiera się na procesie rozeznania sytuacji uzasadniającej takie dopuszczenie ${ }^{36}$. Jak zauważa Zbigniew Janczewski, dokument papieski stanowi przeniesienie przez Kościół problemu „Komunii dla rozwiedzionych” z płaszczyzny kanonicznej, na teologiczno-sakramentalną, opartą o nauczanie teologii moralnej i praktykę penitencjarną ${ }^{37}$.

Adhortacja Amoris laetitia według Rocco Buttiglione, w przeciwieństwie do wcześniejszego podejścia do osób rozwiedzionych i żyjących w nowych związkach, kiedy to mówiło się o domniemaniu całkowitej winy w kontekście grzechu który popełniają, dopuszcza aspekt subiektywny. Tak samo, jak w przypadku grzechów zabójstwa, wyzysku pracowników i wszystkich innych grzechów posiadających ciężką materię. Zatem chociaż rozwód i nowy związek obiektywnie pozostają złem, należy dobrze rozeznać, czy okoliczności nie zdejmują pełnej odpowiedzialności z osoby grzeszącej ${ }^{38}$.

Podobne stanowisko zajął autor niniejszego artykułu. Adhortacje papieża Franciszka - Amoris laetitia i wcześniejsza Evangelii gaudium ${ }^{39}$ uznają fakt, że niektóre osoby żyjące poza małżeństwem

\footnotetext{
${ }^{36}$ L. Martinez Sistach, Come applicare L’Amoris laetitia, Città del Vaticano 2017, s. 88-89.

${ }^{37}$ Z. Janczewski, Udzielanie Komunii..., s. 50.

${ }^{38}$ R. Buttiglione, wywiad z dn. 1.06.2016 r., http://vaticaninsider.lastampa.it/ vatican-insider-polacco/articoli/45221, [dostęp:12. 07.2018, g. 9.45].

${ }^{39}$ Adhortacja apostolska Evangelii gaudium, 24.11.3013, nr 47, AAS 105(2013) s. 1039.
} 
sakramentalnym w drugim związku, nie popełniają grzechu ciężkiego ze względu na różne okoliczności łagodzące, czy też czynniki niejako zmuszające je do takiego sposobu życia. Nie występuje tutaj zatem przesłanka dobrowolności popełnianego grzechu, konieczna dla uznania go za ciężki. Zatem spowiednik, zgodnie z wielowiekową praktyką i nauczaniem doktrynalnym Kościoła, powinien udzielić rozgrzeszenia, a przez to dopuścić do przyjmowania Eucharystii ${ }^{40}$. Nie można powoływać się na zasadę nierozerwalności małżeństwa w przypadku konkretnego grzechu cudzołóstwa, zawieszając przy tym generalne zasady oceny stopnia ciężkości popełnionego grzechu. W przypadku np. morderstwa dokonanego pod wpływem jakiegoś przymusu zewnętrznego, z braku wewnętrznej wolności oceniać grzech tylko jako lekki, a w sytuacjach pokazanych w adhortacji, nie brać pod uwagę przesłanki dobrowolności, koniecznej wraz z świadomością popełnianego zła i jego szczególnie złą materią do oceny grzechu jako śmiertelny ${ }^{41}$. Poza tym $\mathrm{w}$ przypadku, kiedy jakaś osoba została niesprawiedliwie opuszczona przez współmałżonka, nie mając z tego powodu żadnych możliwości korzystania z Bożej łaski płynącej z sakramentu małżeństwa, w imię tegoż sakramentu nie powinna być skazywana, wbrew powołaniu do życia rodzinnego otrzymanego od Stwórcy, na bycie do końca samotną. Kiedy zaś również z innych względów (chociażby dla zapewnienia bytu i wychowania swoich dzieci) nie ma możliwości na trwanie w samotności, nie można jej pozbawiać łaski zjednoczenia w Chrystusie oraz sakramentalnego odpuszczania także innych, popełnianych na co dzień grzechów. Chrześcijanin nie egzystuje na ziemi dla sakramentów, bo to one zostały ustanowione przez Chrystusa, aby móc żyć godnie z Bożą nadprzy rodzoną pomocą. Sakramenty są dla chrześcijan, a nie chrześcijanie dla sakramentów.

Czy zatem zmieniło się spojrzenie Kocioła na możliwość przystępowania do pokuty i Eucharystii przez interesujące nas osoby? Dyscyplina kościelna zawsze ewaluowała i tak z pewnością będzie

\footnotetext{
${ }^{40}$ Z. JAnCZewski, Udzielanie Komunii..., s. 52-53.

${ }^{41}$ Por. Katechizm Kościoła Katolickiego, Poznań 1994, nr 1735.
} 
w przyszłości. Jeszcze na początku XX w. Najmniejszy grzech dotykający materii 6 przykazania Bożego był powszechnie uznawany za śmiertelny, a osobom żyjącym jak brat z siostrą w związku cywilnym po rozpadzie małżeństwa sakramentalnego, odmawiano prawa do przyjęcia Komunii św. W drugiej połowie stulecia to się zmieniło. Papież Franciszek w adhortacji Amoris laetitia zdaje się robić kolejny krok w ewolucji, dotykając sposobu oceny moralnej postępowania wspomnianych osób ${ }^{42}$.

Kardynał Francesco Coccopalmerio uważa, że Kościół postanowił przyznać prawo do sakramentów pokuty i Eucharystii wiernym pozostającym w nieprawym związku dopiero po weryfikacji dwóch istotnych warunków: czy posiadają wolę zmiany swojej sytuacji życiowej oraz czy aktualnie nie istnieją warunki na realizację tej woli. Według zasady nemo iudex i causa sua konieczne jest dokonanie tego autorytetem Kościoła, poprzez udział w rozeznaniu sytuacji proboszcza, kurii, lub nawet biskupa diecezjalnego, poprzez konsultacje i specjalną autoryzację dopuszczenia wiernych do wspomnianych sakramentów. Natomiast Konferencje Biskupów powinny opracować wytyczne pomagające duszpasterzom i zainteresowanym wiernym w postępowaniu podczas rozwiązywania problemów w tej tak delikatnej materii ${ }^{43}$.

Coccopalmerio podkreśla, iż doktryna Kościoła dotycząca nierozerwalności małżeństwa pozostaje wciąż niezmieniona, ponieważ rozbicie związku sakramentalnego jest obiektywnie uznawane za ciężki grzech. Rozgrzeszenie takich osób i dopuszczenie ich do Eucharystii sankcjonuje ich aktualną, obiektywną niemożliwość szybkiej zmiany swojego położenia życiowego, powodującą łagodniejszą ocenę popełnianego przez nich grzechu ${ }^{44}$.

Należy przy tym przypominać Ewangelię uświadamiając, że pragnący być prawdziwymi uczniami Jezusa, są wezwani do bycia z Nim

\footnotetext{
${ }^{42}$ Tamże, s. 53.

${ }^{43}$ F. Coccopalmerio, Il capitolo ottavo della esortazione apostolica post sinodale «Amoris laetitia», Città del Vaticano 2017, s. 27-28.

${ }^{44}$ Tamże, s. 28-29.
} 
w jedności, narzędziami Jego miłosiernej miłości, przezwyciężając każdy rodzaj marginalizacji ${ }^{45}$.

Reasumując, za Gradem należy stwierdzić, że grupa naukowców, zauważających na podstawie papieskiej adhortacji Amoris laetitia możliwości dopuszczania interesujących nas osób do sakramentów uważa, iż nie doszło w tej sytuacji do żadnej doktrynalnej czy dyscyplinarnej zmiany na poziomie zasad. Natomiast otworzyły się nowe możliwości praktyczne na poziomie pojedynczych, niewyczerpanych w swojej różnorodności przypadków ${ }^{46}$.

\section{Aplikacja adhortacji papieża Franciszka do warunków lokalnych}

Pierwszym dokumentem Kościoła partykularnego, umożliwiającym osobom rozwiedzionym na przyjmowanie Eucharystii jest interpretacja biskupów regionu duszpasterskiego Buenos Aires, wydana 5 września 2016 r. Nawiązując do adhortacji Amoris laetitia dokument wprowadza zastrzeżenie, że nie należy mówić o „zgodzie” na dostęp interesujących nas osób do sakramentów, a raczej o „procesie rozeznania" z udziałem duszpasterza. Taka droga nie musi w każdym przypadku prowadzić ostatecznie do udzielenia im sakramentów, ale również kierować ku innym formom większej integracji z życiem Kościoła przez uczestnictwo w grupach duszpasterskich, zaangażowanie w posługi kościelne itp. Jeśli obie strony znajdują się na „drodze wiary” i jest to wykonalne, można im zaproponować życie we wstrzemięźliwości seksualnej, otwierające drogę do sakramentu pojednania. Jeśli zaś w konkretnym przypadku, istnieją ograniczenia zmniejszające odpowiedzialność i winę, zwłaszcza kiedy osoba uważa, że popadałaby w kolejne winy ze szkodą dla dzieci z nowego związku, adhortacja papieska otwiera możliwość dopuszczenia do pojednania i Eucharystii, ponieważ pozwolą one danej osobie na

\footnotetext{
${ }^{45}$ Tamże, s. 56.

${ }^{46}$ P. GRAD, dz. cyt., s. 56.
} 
dalsze dojrzewanie i wzrost mocą łaski. Takiej możliwości nie należy jednak uznawać za bezwarunkowe dopuszczenie do sakramentów ${ }^{47}$.

Jak zauważa Sistach, w świetle cy towanego powyżej dokumentu, ewentualne umożliwienie dostępu do sakramentów zakłada długi proces rozeznawania, którego owocem może się stać powrót na drogę Chrystusa, dzięki formacji i głoszonemu w jej ramach kerygmatowi. Proces nie musi koniecznie skończyć się w każdym przypadku dopuszczeniem do sakramentów, lecz skierować życie osoby zainteresowanej ku innym formom integracji z życiem Kościoła ${ }^{48}$.

W nawiązaniu do licznych polemik dotyczących rozwiązania zaproponowanego przez biskupów argentyńskich, kard. Kasper zauważa, iż dopuszczenie do sakramentów osób rozwiedzionych W wyjątkowych przypadkach opiera się na nauczaniu św. Tomasza z Akwinu i Soboru Trydenckiego. Nie wprowadza niczego nowego, odnawiając jedynie starą tradycję, zawężaną w późniejszych latach. Zawsze bowiem rozróżniano pomiędzy „obiektywną trudnością nakazu moralnego", a w tym przypadku zakazu rozwodu i zrywania małżeństwa, a „ciężarem subiektywnej zdolności winy”. A by to można było określić, należy „,kierując się miłością i mądrością zastanowić się, zastosowanie którego z wymienionych warunków jest bardziej słuszne i lepsze w konkretnej sytuacji. Krytycy Amoris laetitia, zdradzając jednoznaczny obiektywizm moralny, nie dowartościowują znaczenia osobistego sumienia w decyzjach, które tej sfery dotycząa ${ }^{49}$.

Ucinając prowadzone dyskusje i polemiki papież Franciszek dnia 8 września 2016 r. skierował do biskupów regionu Buenos Aires list, w którym stwierdził, że opublikowany przez nich dokument jest bardzo trafny i doskonale wyjaśnia znaczenie rozdziału VIII adhortacji. Ponadto podkreślił, że nie dopuszcza innych interpretacji

\footnotetext{
${ }^{47}$ Obispos de la Region Buenos Aires, Criterios básicos para la aplicación del capitulo VIII de Amoris laetitia, Vida Nueva nr 3004, 2016, s. 24-25.

${ }^{48}$ L. Martinez Sistach, dz. cyt., s. 59-60.

${ }^{49}$ W. Kasper, Dyskusję wokół Amoris laetitia należy już skończyć, https:// www.deon.plhttps://www.deon.pl/religia/kosciol-i-swiat/z-zycia-kosciola/ art,32627,kardynal-kasper-dyskusje-wokol-amoris-laetitia-nalezy-juz-skonczyc. html, [dostęp: 16.07.20018, g. 9.30].
} 
tego fragmentu Amoris laetitia ${ }^{50}$. Ponieważ po liście pojawiły się kolejne dyskusje podważające jego autentyczność, czy rangę, Stolica Apostolska wydała dnia 5 lipca 2017 r. reskrypt, w którym obydwa powyższe pisma, wydrukowane w całości obok tego reskryptu, uznaje za autentyczne nauczanie Magisterium Kościoła ${ }^{51}$.

Zgodnie z przyjmowaną w Kościele zasadą Roma locuta causa finita, umożliwienie interesującym nas osobom przystępowanie do sakramentu pokuty i Eucharystii, według zasad zawartych w dokumencie franciszkowym i biskupów argentyńskich stało się faktem. Papieże stojący przy sterach Łodzi Piotrowej posiadają asystencję Ducha św. W takim aspekcie ich nauczanie służy dobru całego Kościoła, a jego podważanie zazwyczaj prowadzi do głębokich podziałów w łonie tej Wspólnoty. Historia pokazuje zaś, iż racja zazwyczaj leży po ich stronie. Warto w tym kontekście przypomnieć fakt podważania w XVI w. nauczania papieskiego dotyczącego odpustów przez Marcina Lutra i liczne grono poważnych teologów niemieckich. Po pięciuset latach od tamtych wydarzeń, Kościół katolicki wciąż wierzy w skuteczność odpustów i je praktykuje, a działania wspomnianych teologów doprowadziły do poważnej w skutkach religijnych i kulturowych schizmy. Podobnie jak podważanie przez teologów i biskupów krajów zachodnich stanowiska Pawła VI zawartego w encyklice $\mathrm{Hu}$ manae vitae (25.07.1968), odnoszącego się między innymi do naturalnej regulacji poczęć. To nauczanie zostało w praktyce odrzucone przez katolików i wielu teologów Europy zachodniej, która po pięćdziesięciu latach od jej powstania, boryka się aktualnie z poważnym kryzysem demograficznym.

Nauczanie papieża Franciszka zostało między innymi przyjęte przez biskupów Konferencji Episkopatu Niemiec. W dokumencie z 1 lutego 2017 r. zachęcają oni najpierw każdego, kto posiada wątpliwości w odniesieniu do ważności swojego małżeństwa, aby poddał je ocenie sądowi kościelnemu. Ponadto zauważają, że adhortacja Amoris laetitia umożliwia rozpoczęcie procesu rozeznania, opartego na ocenie

\footnotetext{
${ }^{50}$ Epistula apostolica, AAA 58(2016) nr 10, s. 1071-1074.

${ }^{51}$ Rescriptum „Ex audientia SS.mi”, AAA 58(2016) nr 10, s. 1074.
} 
sumienia osoby zainteresowanej, której na tej drodze towarzyszy duszpasterz. Proces takowy, w oparciu o sumienie może doprowadzić osobę rozwiedzioną po zawarciu związku cywilnego do korzystania z sakramentów pokuty i Eucharystii. Nie musi się jednak to stać we wszystkich przypadkach. Stąd też szacunek należy się zarówno osobom, których proces rozeznania doprowadził do sakramentów, jak też i pozostałym. Należy pamiętać, iż wierni są zobowiązanie do ciągłego formowania własnego sumienia ${ }^{52}$. Istotnym w powyższym dokumencie jest uznanie faktu, że proces rozeznania dokonywanego przez zainteresowanego wiernego wraz z pomocą jego duszpasterza, polegający między innymi na formowaniu jego sumienia, może doprowadzić osobę rozwiedzioną do pełnego uczestnictwa w sakramentalnym życiu Kościoła.

Podobny dokument został wydany przez Biskupa Wojskowego Ordynariatu Kanady. Nosi on datę 22 lutego 2017 r. Biskup Scott C. Mc Caig stwierdza, że adhortacja papieska przy dopuszczaniu do sakramentów osób rozwiedzionych, żyjących w powtórnych związkach bez stwierdzenia nieważności małżeństwa sakramentalnego przewiduje nie tylko sytuacje, kiedy zachowują one abstynencję seksualną. Dotyczy również przypadków, w których strona zgadza się na współżycie seksualne wbrew swojej woli, na przykład ze względu na dobro posiadanych dzieci, jeżeli rezygnacja z życia na wzór małżeńskiego grozi poważnymi konsekwencjami. W takich bowiem okolicznościach może nie być ona winna popełnienia ciężkiego grzechu. Podobnie zresztą, jak przy ocenie winy moralnej stosowania antykoncepcji, gdy jeden z małżonków nie zgadza się na jej użycie przez drugiego. Przyjmowanie powyższych zasad wprost do osób rozwiedzionych, będących w powtórnych związkach w dokumencie papieskim jest postrzegane jako rozwój doktryny Kościoła. Autor dokumentu dodaje,

\footnotetext{
${ }^{52}$ „Die Freude der Liebe, die in den Familien gelebt wird, ist auch die Freude der Kirche“. Einladung zu einer erneuerten Ehe- und Familienpastoral im Licht von Amoris laetitia, https://www.dbk.de/fileadmin/redaktion/diverse_downloads/ presse_2017/2017-015a-Wortlaut-Wort-der-Bischoefe-Amoris-laetitia.pdf, s. 6, [dostęp: 16.07.2018, g. 10.30].
} 
że jest jednak mało prawdopodobne wystąpienie dużej liczby przypadków kwalifikujących się pod nauczanie zawarte w Amoris laetitia oraz normy zawarte w promulgowanym przez niego piśmie ${ }^{53}$.

Problemem aplikacji papieskiej adhortacji do warunków polskich zajęła się również Konferencja Episkopatu Polski. Owocem tego są wytyczne pastorale z 8 czerwca b.r. Dokument przytacza obszerne fragmenty adhortacji.

Zauważając złożoność sytuacji wiernych związanych węzłem małżeńskim i nie mogących $z$ tego powodu zawrzeć małżeństwa sakramentalnego z osobą, z którą pozostają w związku pozasakramentalnym, należy rozważyć w poszczególnych przypadkach możliwość wnikliwego rozeznania ich sytuacji. To rozeznanie powinno najpierw prowadzić do udzielenia na drodze kościelnego procesu sądowego odpowiedzi na pytanie, czy można stwierdzić nieważność pierwszego związku małżeńskiego. W przypadku, gdy prawomocnym wyrokiem sądu kościelnego nieważność nie zostanie stwierdzona, należy kontynuować rozeznanie o charakterze duszpasterskim, które jako niełatwe i niezwykle odpowiedzialne zadanie wymaga solidnego przygotowania duszpasterzy. Trzeba rozeznać, czy wspomniane powyżej osoby zachowują wierność, poświęcają się dla dzieci, angażują się w życiu chrześcijańskim, świadome są nieprawidłowości swego związku i życia w grzechu, pragnęłyby zmienić sytuację, w której się znajdują, lecz nie mogą tego uczynić bez zaciągnięcia kolejnej winy (np. problem odpowiedzialności za wychowanie dzieci). Rozeznanie $\mathrm{w}$ formie indywidualnego i konsekwentnego, długotrwałego kierownictwa duchowego może prowadzić do różnych, coraz głębszych form integracji ze wspólnotą kościelną. Podjęcie odpowiedniej decyzji, wspólnie przez kierownika duchowego i zainteresowaną osobę będące owocem procesu rozeznania, nie może nastąpić po jednym czy nawet

${ }^{53}$ On the Implementation of Chapter Eight of the Apostolic Exhortation Amoris Laetitia in the Military Ordinariate of Canada, http://www.rcmilord.com/media/ On-the-Implementation-of-Chapter-Eight-of-the-Apostolic-Exhortation-Amoris-Laetitia-in-the-Military-Ordinariate-of-Canada-22-Feb-17.pdf, s. 9-10, [dostęp: 16.07.2018, g. 11.05]. 
kilku powierzchownych spotkaniach. Wymaga także konsultacji z kompetentnym duszpasterzem posługującym przy sądzie biskupim lub w diecezjalnym ośrodku duszpasterstwa rodzin ${ }^{54}$.

Wydaje się, że wytyczne Konferencji Episkopatu Polski w odniesieniu do dwóch wcześniej cy towanych, są dokumentem najbardziej dojrzałym i przemyślanym. Przekazują czytelnikowi nauczanie papieskie oraz próbują go aplikować do warunków życia polskiego Kościoła. Precyzują, co należy uznać za przedmiot rozeznania (np. zachowanie wzajemnej wierności, poświęcenie dla dzieci), wskazując równocześnie na długotrwałość i złożoność tego procesu, wynikającą także z konieczności odbycia fachowych konsultacji kanoniczno-duszpasterskich. Celem podejmowanego rozeznania ma się stać doprowadzenie do coraz bardziej głębokich form integracji z Kościołem. Chociaż w wytycznych nie wspomina się o tym wprost, również nie wyklucza się najgłębszej integracji, czyli dopuszczenia do pełnego uczestnictwa w sakramentach.

Przytoczone powyżej dokumenty, będące próbami aplikacji papieskiej adhortacji do warunków lokalnych posiadają zasadniczo charakter ogólny. Należałoby się zatem zastanowić, jakie konkretne wymagania powinna spełniać osoba pragnąca uzyskać dopuszczenie Kościoła do przyjęcia sakramentów pokuty oraz Eucharystii.

Proces rozeznania, jak to już proponował autor powyższej publikacji przed powstaniem adhortacji, należałoby rozpocząć od skierowania zainteresowanej osoby do sądu kościelnego, aby ten rozpatrzył, czy rozbite małżeństwo było ważne z punktu widzenia prawa kanonicznego. Wiąże się to $\mathrm{z}$ faktem, iż wierni na pierwszym miejscu posiadają obowiązek życia w małżeństwie sakramentalnym i mogą zachodzić okoliczności zezwalające na zawarcie kolejnego związku

\footnotetext{
${ }^{54}$ Wytyczne pastoralne do adhortacji Amoris laetitia, pkt 4, https://ekai.pl/dokumenty/wytyczne-pastoralne-do-adhortacji-amoris-laetitia/, [dostęp: 16.07.2018, g. 12.05].
} 
jako sakramentalnego ${ }^{55}$. W tym kierunku poszły też cytowane powyżej wytyczne pastoralne Konferencji Episkopatu Polski i Niemiec ${ }^{56}$.

W przypadku kiedy po przeprowadzeniu procesu sądowego został wydany wyrok negatywny, czyli stwierdzający, że nie została udowodniona nieważność małżeństwa, duszpasterz prowadzący proces rozeznania na rzecz strony zainteresowanej, zapoznając się z brzmieniem pisma sądowego zawierającego wyrok, powinien stwierdzić, czy nie został on wydany z powodu braku dowodów, szczególnie niemożliwości przedstawienia świadków. Często zdarza się bowiem, że w procesach, prowadzonych po dłuższym czasie od zawarcia i rozpadu małżeństwa sakramentalnego, strony nie są w stanie podać świadków potwierdzających ich sytuację, ponieważ po okresie 20-30, a nawet więcej lat takowi już nie żyją, albo nie pamiętają istotnych dla sprawy faktów. Stąd mimo okoliczności wskazujących na nieważność rozpatrywanego małżeństwa i subiektywnej pewności o nieważności swojego małżeństwa w sumieniu osoby zainteresowanej, sędziowie nie mogą wydać wyroku pozytywnego. Natomiast adhortacja papieska wspomina właśnie o takich przypadkach ${ }^{57}$.

Jeżeli powyższe ustalenia przyniosą wynik negatywny, trzeba stwierdzić, czy prosząca o sakramenty strona, została niesprawiedliwie porzucona przez współmałżonka odchodzącego do osoby trzeciej oraz czy, nie istnieje już możliwość pogodzenia się stron i powrotu do wspólnego życia w małżeństwie.

Poza taką sytuacją należy dowiedzieć się, czy od rozejścia się stron nie upłynęło już bardzo wiele czasu, na przykład 20 lub więcej lat i w związku z tym bez względu na to, kto zostawił współmałżonka, nawet jeśli była to osoba prosząca o sakramenty, ugruntowana sytuacja osobista i rodzinna obydwu stron uniemożliwia na powrót do wspólnego życia sakramentalnego.

Po ustaleniu powyższych faktów i uzyskaniu pozytywnej odpowiedzi na któreś z wyżej przedstawionych pytań, należałoby przejść

\footnotetext{
${ }^{55}$ Z. JANCZewski, Udzielanie Komunii..., s. 54.

${ }^{56}$ Wytyczne pastoralne do adhortacji Amoris laetitia..., pkt 4.

${ }^{57} \mathrm{AL}, \mathrm{nr} 298$.
} 
do dalszych etapów rozeznania. Istotne jest teraz stwierdzenie, czy obecny związek strony nosi cechy trwałości, a więc został usankcjonowany cywilnie, nie będąc jedynie konkubinatem. Czynnikiem przymuszającym niejako w nim do pozostawania razem są wychowywane dzieci, zrodzone z tego, lub poprzedniego związku. Innym czynnikiem może być zależność finansowa od drugiej strony, a w związku z tym pozostanie bez środków do życia po odejściu, a także stałe zapewnianie opieki jednej ze stron cierpiącej na poważną chorobę. Trzeba ustalić, czy w obecnym związku zachowywana jest wierność, a dzieciom rzeczywiście zapewnia się odpowiednie wychowanie, także religijne.

Rozeznanie powinno również dotyczyć sytuacji duchowej proszącego. A zatem, czy poza problemem pozostawania w grzechu cudzołóstwa i świadomości tego faktu, stara się on prowadzić życie zgodne $\mathrm{z}$ wiarą, wypełniając obowiązki religijne. W przypadku kiedy tak nie jest, nadarza się okazja aby pomóc stronie w powrocie do życia wiarą zgodnie z zasadami Ewangelii. Trzeba więc rozpocząć proces nawracania, przez regularne spotkania $z$ duszpasterzem trwające dłuższy okres czasu, na przykład pół roku. Po nim dopiero, kiedy wierny rozpocznie regularne wypełnianie obowiązków chrześcijańskich i życie wiarą, nadrabiając niejako powstałe w tym względzie zaległości, stanie się możliwe jego dopuszczenie do sakramentów pojednania i Eucharystii.

\section{Zakończenie}

Niektórzy z małżonków decydują się czasami na odejście i życie $\mathrm{z}$ inną osobą $\mathrm{w}$ związku niesakramentalnym, popełniając grzech ciężki i pozbawiając się tym samym prawa do Eucharystii. Z czasem pojawia się u pewnej części z nich pragnienie powrotu do życia w pełnej wspólnocie z Kościołem, w tym również wspólnocie sakramentalnej. Jednakże zobowiązania zaciągnięte wobec nowego partnera, czy dzieci, nie pozwalają na porzucenie obecnego związku. Rozwiązywaniem tego rodzaju problemów zajął się papież Franciszek zwołując w roku 2015 Zwyczajny Synod Biskupów oraz wydając 
posynodalną adhortację Amoris laetitia, która wzbudziła w Kościele katolickim wiele kontrowersji.

Należy zauważyć, iż już przed wspomnianymi synodami w środowiskach naukowych pojawiły się dyskusje dotyczące powyższych problemów. Przykładowo, włoski naukowiec Ceretti w swojej monografii wyszedł od postanowienia starożytnego Soboru Nicejskiego, w duchu którego dopuszczenie osób rozwiedzionych, żyjących w związkach niesakramentalnych do sakramentów pokuty i Eucharystii, stałoby się znakiem miłosierdzia okazywanego przez Pana Boga, a także zrozumienia ich trudnej sytuacji przez wspólnotę kościelną.

Autor niniejszego artykułu w publikacji poprzedzającej wspomniany Synod Biskupów z 2015 roku zauważał, że wyznawcy Prawosławia stosują tzw. zasadę oikonomii, która ma prowadzić osoby rozwiedzione do zbawienia, umożliwiając upadłym na skutek grzechu osiągnięcie życia wiecznego. Prawosławni uważają zatem, iż nie należy pozostawiać małżonków bez udziału łaski płynącej z przyjmowania Komunii św. Tolerowanie kolejnego, już niesakramentalnego związku w kontekście przystępowania do Eucharystii, jest dla niekatolickich Kościołów wschodnich lekarstwem i ochroną, aby na stałe nie utrzymywać wspomnianych osób w grzechu. Ponadto, omawiając interesujące nas kwestie, dostrzega pewną analogię do katolickiego postrzegania swoich wiernych, zawierających za dyspensą związek małżeński z osobami nieochrzczonymi. Takie małżeństwo jest tolerowane przez Kościół katolicki, pomimo że nie uważa się go za sakramentalne, a katolicki małżonek zachowuje możliwość przyjmowania Komunii św.

W kontekście możliwości rozgrzeszenia stawia również pytanie, czy na działanie w pełni dobrowolne decyduje się np. osoba nie posiadająca warunków aby samotnie wychować i utrzymać swoje dzieci, które przyszły na świat z jej sakramentalnego, lub kolejnego małżeństwa. Jeżeli zatem jej wolność wewnętrzna jest ograniczona, grzech który popełnia nie spełnia jednej z trzech przesłanek koniecznych do uznania go za ciężki, czyli uniemożliwiający przyjmowania Eucharystii. Ponadto wychodząc z Chrystusowego założenia, że to nie człowiek jest dla szabatu, a szabat dla człowieka, można analogicznie 
powiedzieć, iż nie człowiek został stworzony dla sakramentów, tylko sakramenty dla niego, aby pomagać mu w osiąganiu ideału świętości.

Należy mocno podkreślić, iż to Jan Paweł II, a nie Franciszek, stał się pierwszym papieżem dopuszczającym wiernych żyjących po rozpadzie związku sakramentalnego, z nowymi osobami na tzw. kontrakcie cywilnym, do przyjmowania Komunii św. Stworzyło to poważne novum w Kościele. Ponadto, uświadomił on fakt, iż główną przeszkodę dla udzielania im Eucharystii stanowi nie wcześniejszy czyn odejścia od współmałżonka, godzący w nierozerwalność małżeństwa sakramentalnego, który czasami może być już nieodwracalny, ale ciągłe trwanie w grzechu ciężkim poprzez współżycie seksualne z nowym partnerem w związku cywilnym, czyli popełnianie grzechu cudzołóstwa.

Natomiast papież Franciszek w adhortacji Amoris laetitia zauważa, że stopień odpowiedzialności małżonków za rozpad ich związku nie jest równy w każdym przypadku, stąd mogą wystąpić czynniki ograniczające zdolność podejmowania przez nich decyzji. W odniesieniu do dyscypliny sakramentalnej po procesie rozeznania można więc uznać, że w danej sytuacji nie zaistniała poważna wina. Papież zachęca do odpowiedzialnego rozeznania, osobistego i duszpasterskiego każdego indywidualnego przypadku. Biorąc pod uwagę konkretne warunki i okoliczności, należy bardziej doceniać rolę sumienia w praktyce Kościoła, szczególnie w niektórych sytuacjach, obiektywnie odbiegających od katolickiego rozumienia małżeństwa. Ze względu na uwarunkowania i czynniki łagodzące, jest możliwe, że pośród pewnej obiektywnej sytuacji grzechu, osoba która nie jest subiektywnie, albo w pełni winna, może jednak żyć w łasce Bożej.

Przytoczone w niniejszej publikacji opinie jednej z grup uczonych wskazują, że adhortacja Amoris laetitia jest tylko potwierdzeniem nauczania poprzednich papieży i nie wnosi niczego nowego ani do doktryny o małżeństwie, ani też do dyscypliny Kościoła. Inni, w tym kard. Coccopalmerio uważają, że Kościół postanowił przyznać prawo do sakramentów pokuty i Eucharystii wiernym pozostającym w nieprawym związku, po weryfikacji istotnych okoliczności: czy posiadają wolę zmiany swojej sytuacji życiowej oraz czy aktualnie nie istnieją 
warunki na realizację tej woli. Według zasady nemo iudex i causa sua konieczne jest dokonanie tego autorytetem Kościoła, poprzez udział w rozeznaniu sytuacji proboszcza, kurii, lub nawet biskupa diecezjalnego, poprzez konsultacje i specjalną autoryzację dopuszczenia wiernych do wspomnianych sakramentów. Natomiast Konferencje Biskupów powinny opracować wytyczne pomagające duszpasterzom i zainteresowanym wiernym $\mathrm{w}$ postępowaniu podczas rozwiązywania problemów w tej delikatnej materii.

Pierwszym dokumentem Kościoła partykularnego, który umożliwił osobom rozwiedzionym na przyjmowanie Eucharystii była interpretacja biskupów regionu duszpasterskiego Buenos Aires z września 2016 r. Ewentualne umożliwienie dostępu do sakramentów zakłada długi proces rozeznawania, którego owocem może się stać powrót na drogę Chrystusa, dzięki formacji i głoszonemu w jej ramach kerygmatowi. Proces nie musi skończyć się w każdym przypadku dopuszczeniem do sakramentów, lecz skierować życie osoby zainteresowanej ku innym formom integracji z życiem Kościoła.

Ucinając prowadzone na interesujący nas temat dyskusje i polemiki, papież Franciszek w 2016 r. skierował do biskupów regionu Buenos Aires list, w którym stwierdził, że opublikowany przez nich dokument jest trafny, doskonale wyjaśniając znaczenie adhortacji. Podkreślił, również, iż nie dopuszcza innych interpretacji Amoris laetitia. Ponieważ po tym liście pojawiły się kolejne dyskusje podważające jego autentyczność, czy rangę, Stolica Apostolska wydała dnia 5 lipca 2017 r. reskrypt, w którym obydwa powyższe pisma, wydrukowane w całości obok tego reskryptu, uznaje za autentyczne nauczanie Magisterium Kościoła.

Recepcja nauczania papieża Franciszka rozpoczęła się od Niemiec. Konferencja Biskupów tego kraju w dokumencie wprowadzającym w życie adhortację stwierdza, że Amoris laetitia umożliwia rozpoczęcie procesu rozeznania, opartego na ocenie sumienia osoby zainteresowanej, której na tej drodze towarzyszy duszpasterz. Proces takowy, w oparciu o sumienie może doprowadzić osobę rozwiedzioną po zawarciu związku cywilnego do korzystania z sakramentów pokuty 
i Eucharystii. Podobny dokument został następnie wydany przez Biskupa Wojskowego Ordynariatu Kanady.

Problemem aplikacji papieskiej adhortacji do warunków polskich zajęła się Konferencja Episkopatu Polski. Owocem tego są wytyczne pastorale z 8 czerwca 2018 r. Dokument przytacza obszerne fragmenty adhortacji. Zauważa, iż rozeznanie w formie indywidualnego i konsekwentnego, długotrwałego kierownictwa duchowego może prowadzić do różnych, coraz głębszych form integracji ze wspólnotą kościelną. Podjęcie odpowiedniej decyzji, wspólnie przez kierownika duchowego i zainteresowaną osobę będące owocem procesu rozeznania, nie może nastąpić po jednym czy nawet kilku powierzchownych spotkaniach. Wymaga konsultacji z kompetentnym duszpasterzem. Wytyczne Konferencji Episkopatu Polski w odniesieniu do dwóch wcześniej cytowanych, są dokumentem najbardziej dojrzałym i przemyślanym. Przedstawiają zainteresowanym nauczanie papieskie oraz próbują aplikować papieską adhortację do warunków życia polskiego Kościoła. Precyzują, co należy uznać za przedmiot rozeznania, wskazując równocześnie na długotrwałość i złożoność tego procesu, wynikającą także z konieczności odbycia fachowych konsultacji kanoniczno-duszpasterskich. Celem podejmowanego rozeznania ma się stać doprowadzenie do coraz bardziej głębokich form integracji z Kościołem. Chociaż w dokumencie nie wspomina się o tym wprost, również nie wyklucza się najgłębszej integracji, czyli dopuszczenia do pełnego uczestnictwa w sakramentach.

Dokonując recepcji nauczania papieża Franciszka, należałoby teraz ustalić bardziej szczegółowo etapy i kryteria procesu rozeznania. Wspomniany proces należałoby rozpocząć od skierowania zainteresowanej osoby do sądu kościelnego, aby ten rozpatrzył, czy rozbite małżeństwo było ważne z punktu widzenia prawa kanonicznego. W przypadku kiedy po przeprowadzeniu procesu sądowego został wydany wyrok negatywny, czyli stwierdzający, że nie została udowodniona nieważność małżeństwa, duszpasterz prowadzący rozeznanie na rzecz strony zainteresowanej, zapoznając się z brzmieniem pisma sądowego zawierającego wyrok, powinien stwierdzić, czy nie został on wydany z powodu braku dowodów, szczególnie niemożliwości 
przedstawienia świadków. Trzeba również próbować ustalić, czy prosząca o sakramenty strona, została niesprawiedliwie porzucona przez współmałżonka odchodzącego do osoby trzeciej oraz czy, nie istnieje już możliwość pogodzenia się stron i powrotu do wspólnego życia w małżeństwie. Następnie należałoby przejść do dalszych etapów rozeznania. Istotne jest teraz stwierdzenie, czy obecny związek strony nosi cechy trwałości, a więc został usankcjonowany cywilnie, nie będąc jedynie czasowym, nietrwałym konkubinatem. Duszpasterz ma również za zadanie ustalenie, czy występuje tu czynnik niejako przymuszający zainteresowaną osobę do pozostawania w związku niesakramentalnym, taki jak konieczność wspólnego wychowywania dzieci zrodzonych z tego, lub poprzedniego związku. Innym czynnikiem może być zależność finansowa od drugiej strony, a w związku z tym pozostanie bez środków do życia po odejściu, a także stałe zapewnianie opieki jednej ze stron cierpiącej na poważną chorobę. Trzeba ponadto ustalić, czy w obecnym związku zachowywana jest wierność, a dzieciom rzeczywiście zapewnia się odpowiednie wychowanie, także religijne. Podczas procesu rozeznania nadarza się znakomita okazja, aby pomóc biorącej w nim udział stronie, w powrocie do życia wiarą zgodnie z zasadami Ewangelii.

\section{Reception problem of Apostolic exhortation Amoris leatitia in terms of admission to sacraments penance and holy communion divorced persons}

In the year 2015 pope Francis issued Apostolic exhortation Amoris laetitia. This document raises among other things the problem admission to sacraments penance and holy communion divorced persons. The first part of this article concerns scientific discussion about sacraments for divorced persons before 2014 year. Next part is about receiving the Body of the Lord according to the Familiaris consortio i Amoris laetitia. On the third part are canonists and theologian interpretations of the popes Francis exhortation. Last part of article is about application of this document to local conditions in the word. 
SŁowA KLUCzowe: Adhortacja Amoris laetitia; osoby rozwiedzione; Komunia św.; sakrament pokuty; rozeznanie

KEY wORDs: Exhortation Amoris laetitia; divorced persons; holy communion; sacrament of penance; discernment

\section{Nota o Autorze:}

Ks. PROF. ZW. DR HAB. ZBIGNIEW JANCZEWSKI - pracownik naukowo-dydaktyczny na Wydziale Prawa Kanonicznego Uniwersytetu Kardynała Stefana Wyszyńskiego w Warszawie, kierownik Katedry Prawa o Posłudze Uświęcania. Członek Centralnej Komisji do Spraw Stopni i Tytułów, Przewodniczący Rady Naukowej Instytutu Ochrony Danych Osobowych przy Konferencji Episkopatu Polski. 